\title{
TEKNIK PEMBENIHAN LOBSTER AIR TAWAR RED CLAW (Cherax quadricarinatus) DI UNIT PEMBENIHAN BUDIDAYA AIR TAWAR (UPBAT) PUNTEN KOTA BATU JAWA TIMUR
}

\author{
Hatchery Technique of Fresh water Lobster Red Claw (Cherax \\ quadricarinatus) at Board of Freshwater Aquaculture Unit Punten Batu East \\ Java
}

\author{
Ernawati $^{1}$, Chrisbiyantoro ${ }^{2}$ \\ ${ }^{1}$ Staf Pengajar di Fakultas Pertanian, Universitas Yudharta Pasuruan \\ email : ernawati.hariyadi@yahoo.com \\ ${ }^{2}$ Staf PNS Dinas Kelautan dan Perikanan Provinsi Jawa Timur, UPBAT Punten Batu
}

\begin{abstract}
ABSTRAK
Lobster air tawar merupakan salah satu komoditi perikanan yang memiliki kandungan gizi yang cukup tinggi terutama protein, mempunyai karakter tidak mudah stress dan tidak mudah terserang penyakit. Asalkan teknik pembenihan, kebutuhan pakan, dan kualitas air terpenuhi maka lobster dapat tumbuh dan berkembang cepat, serta memiliki daya bertelur yang tinggi. Tujuan kegiatan ini adalah untuk mengetahui secara langsung teknik pembenihan lobster air tawar di UPBAT Punten Batu. Metode yang digunakan adalah metode pengumpulan data yang terdiri atas data primer dan sekunder. Data primer adalah data yang diperoleh dengan melakukan observasi yaitu dengan melakukan peninjauan dan pengamatan secara langsung di lapangan sedangkan data sekunder berupa data yang diperoleh dari berbagai literatur yang berkaitan dengan kegiatan pembenihan lobster air tawar. Teknik pembenihan lobster air tawar di UPBAT Punten Batu dilakukan secara intensif dengan kegiatan meliputi : pengadaan dan seleksi induk, pemijahan, pengeraman, pemeliharaan benih, pemberian pakan, pengelolaan dan pengaturan kualitas air, pemanenan, pengemasan dan pemasaran. Produksi benih yang dihasilkan pertahun adalah 12.000 ekor benih dengan Survival Rate (SR) sebesar $80 \%$. Induk yang dipijahkan adalah induk matang gonad berusia 5-6 bulan dengan panjang tubuh 4-5 inci. Hasil rata-rata pengukuran kualitas air di UPBAT adalah suhu berkisar 25$26{ }^{\circ} \mathrm{C}, \mathrm{pH}$ antara 7-8 dan DO berkisar 5,2-6 ppm.
\end{abstract}

Kata kunci : lobster air tawar, pembenihan, UPBAT

Freshwater crayfish is one of the fishery commodities that has a high nutrient content especially protein, has the character not easily stressed and not susceptible to disease. Provided seeding technique, feed requirements, and water quality are met then the lobsters can grow and evolve rapidly, and has a high spawn. The aim of this activity is to determine the direct seeding technique crayfish in UPBAT Punten Batu. The method used is the method of data collection which consists of primary and secondary data. Primary data is obtained by observation is by reviewing and direct observations in the field, while secondary data obtained from the literature relating to the activities of freshwater lobster hatchery. Freshwater lobster hatchery techniques in UPBAT Punten Batu city intensively with activities include: procurement and parent selection, spawning, incubation, seed maintenance, feeding, management and control of water quality, harvesting, packaging and marketing. Production of seeds produced per year is 12,000 fry with Survival Rate (SR) of $80 \%$. Spawning parent is the parent mature gonads 5-6 months old with a body length of 4-5 inches. The average yield of water quality measurements in UPBAT have the temperature range $25-26{ }^{\circ} \mathrm{C}, \mathrm{pH}$ between $7-8$ and $\mathrm{DO}$ ranged from 5.2 to $6 \mathrm{ppm}$.

Keywords : Freshwater crayfish, hatchery, UPBAT 


\section{PENDAHULUAN}

Lobster air tawar (Cherax quadricarinatus) merupakan salah satu komoditi perikanan yang mempunyai bentuk tubuh yang unik serta memiliki warna khas dan beragam. Lobster yang dikenal oleh masyarakat selama ini adalah udang yang berasal dari tangkapan di laut dan belum bisa dibudidayakan. Lobster air tawar (LAT) ini memiliki keunggulan dibandingkan lobster laut, diantaranya sudah dapat dibudidayakan dan teknik budidayanya lebih mudah dibanding udang windu dan udang galah. Perkembangan hidupnya sederhana tanpa melalui stadia larva yang rumit (nauplius, zoea, mysis, postlarva) seperti pada udang (Holdich,1993 dalam Susanto, 2010). Menurut Iskandar (2003), hidangan lobster air tawar digemari karena dagingnya yang padat, pejal, empuk dan rasanya cukup gurih, terutama jika dibandingkan dengan lobster air laut atau jenis udang lainnya. Lobster air tawar juga memiliki kandungan gizi yang cukup tinggi terutama protein.

Kelebihan lain lobster air tawar yaitu karakternya tidak mudah stress dan tidak mudah terserang penyakit, asalkan kebutuhan pakan, kualitas air dan kebutuhan oksigen terpenuhi maka lobster dapat tumbuh dan berkembangcepat, serta memiliki daya untuk bertelur yang tinggi (Wiyanto dan Hartono, 2003). Jika dilihat dari kondisi iklim dan siklus musimnya memungkinkan lobster untuk dibudidayakan sepanjang tahun. Dengan potensi iklim yang sangat mendukung dan sumber pakan alami yang cukup tersedia di alam dan mudah diperoleh, maka lobster akan tumbuh dengan cepat (Wiyanto dan Hartono, 2006).

Sebenarnya permintaan pasar terutama pasar ekspor terhadap lobster air tawar cukup tinggi. Sejumlah negara telah meminta lobster air tawar, baik dalam keadaan hidup maupun beku. Jepang merupakan potensi pasar yang paling besar di Asia. Selain Jepang, negara Asia lainnya seperti Malaysia, Hongkong, Cina, Taiwan, Korea dan Singapura juga mengimpor lobster. Negara lain seperti Amerika Serikat, Kanada, Perancis, Belanda, Jerman, Belgia, Selandia Baru dan Australia juga menggemari lobster air tawar sebagai makanan favorit. Sedangkan pasar lobster dalam negeri seperti Jakarta, Surabaya dan Bali juga cukup ramai (Wiyanto dan Hartono, 2003).

Keberhasilan budidaya lobster air tawar sangat dipengaruhi oleh ketersedian benih yang berkualitas. Lukito dan Prayugo (2007) menyatakan bahwa keberhasilan lobster air tawar sangat dipengaruhi oleh keberhasilan pada teknis pembenihan yang dilakukan. Pembenihan lobster air tawar di UPBAT Punten sudah dilakukan dan dikembangkan sejak tahun 2005. Kegiatan ini dilakukan dengan tujuan untuk mempelajari teknik pembenihan lobster air tawar (Cherax quadricarinatus) yang dikembangkan di UPBAT Punten Batu Jawa Timur.

\section{BAHAN DAN METODE Peralatan dan Bahan}

Peralatan yang digunakan untuk usaha pembenihan lobster air tawar yaitu : akuarium, selang plastik, heater, saringan, paralon kecil untuk persembunyian lobster, penumbuk pakan dan aerator. Sedangkan bahanbahan yang digunakan adalah 3 (tiga) set induk lobster air tawar yang setiap setnya terdiri dari 3 jantan dan 5 betina berumur 5-6 bulan, pakan udang dan orsitetrasiklin sebagai obat-obatan untuk menanggulangi penyakit yang biasanya menyerang lobster.

\section{Metode \\ Prosedur Kerja dan Pengumpulan Data}

Teknik pembenihan lobster air tawar dilakukan sesuai prosedur kerja balai setempat yaitu persiapan wadah (mencuci dan mengeringkan wadah selama \pm 2 hari), pembuatan saluran 
pemasukan dan pengeluran air menggunakan pipa paralon PVC 3/4 inci, memasang shelter berupa pipa paralon serta aerasi disetiap sudut kolam/wadah. Selanjutnya dilakukan seleksi induk, dan pemijahan induk pada kolam. Proses pemijahan berlangsung selama 10-15 hari. Induk yang telah bertelur ditangkap menggunakan tangan dan di masukkan dalam akuarium pengeraman $(60 \times 40 \times 60 \mathrm{~cm})$ secara individu. Lama waktu pengeraman berkisar 35-45 hari. Telur yang telah menetas dibiarkan dalam akuarium pengeraman selama 7 hari sampai benih bergerak aktif. Pemeliharaan benih dilakukan di dalam akuarium berukuran $50 \mathrm{~cm} \times 50 \mathrm{~cm} \times 100 \mathrm{~cm}$ selama satu bulan. Ukuran panjang benih rata-rata $0.71 \mathrm{~cm}$ dan berat 0.026 gram. Setelah itu dilakukan pembesaran juvenil. Pengukuran kualitas air meliputi suhu, pH dan DO.

Data yang dikumpulkan terdiri atas data primer dan sekunder. Data primer adalah data yang diperoleh dengan melakukan observasi yaitu dengan melakukan peninjauan dan pengamatan secara langsung di lapangan sedangkan data sekunder berupa data yang diperoleh dari berbagai literatur yang berkaitan dengan kegiatan pembenihan lobster air tawar.

\section{HASIL DAN PEMBAHASAN}

\section{A. Seleksi Induk}

Kualitas induk sangat berpengaruh terhadap kualitas benih yang dihasilkan. Seleksi dilakukan setiap bulan meliputi seleksi jenis kelamin, ukuran tubuh dan kualitas calon induk. Menurut Iskandar (2003), lobster yang dipilih sebagai calon induk panjang tubuhnya harus sudah mencapai 5-6 $\mathrm{cm}$ agar didapat lobster yang sudah matang gonad. Selain itu lobster indukan harus memiliki nafsu makan yang tinggi, fisik bongsor, capit lengkap, gerakan lincah dan warna tubuhnya cerah.

\section{B. Pemijahan}

Kegiatan pemijahan dilakukan di akuarium pemijahan. Sebelum digunakan akuarium pemijahan dibersihkan dahulu dengan cara digosok dengan spon lalu dibilas dengan air, setelah itu dasar akuarium ditata roaster atau paralon dengan pola berjajar atau memanjang. Selanjutnya selang aerasi ditata merata ke masing-masing akuarium. Induk lobster yang dipijahkan adalah 5 set induk (terdiri dari 15 jantan dan 25 induk betina) untuk ukuran akuarium 50x100 $\mathrm{cm}$ dengan tinggi 50 $\mathrm{cm}$. Menurut Setiawan (2006), jenis dan konstruksi wadah pemeliharaan calon induk lobster air tawar sangat tergantung pada ukuran dan tingkat kepadatan. Kepadatan yang ideal adalah $10 \mathrm{ekor} / \mathrm{m}^{2}$ untuk calon induk berat rata-rata 15 gram dan 5 ekor $/ \mathrm{m}^{2}$ dengan ukuran berat rata-rata 20 gram. Sedangkan untuk calon induk berat rata-rata 30 gram, padat tebar yang ideal adalah 1-2 ekor $/ \mathrm{m}^{2}$. Gambar 2 berikut ini adalah perbedaan jenis kelamin induk lobster jantan dan betina

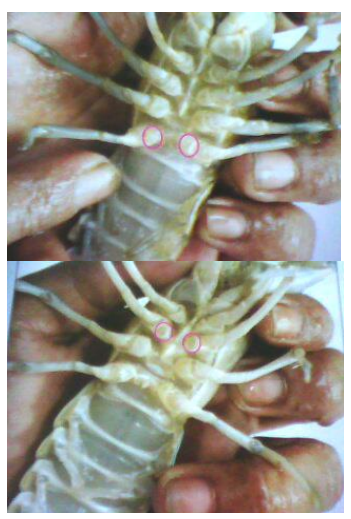

Gambar 2. Perbedaan Induk Lobster Jantan (kiri) dan Betina (kanan).

Sumber : Lengka dkk (2013)

Pada Gambar 2 dapat dilihat bahwa lobster jantan memiliki tonjolan didasar tangkai kaki jalan ke-5 jika penghitungan dimulai dari kaki jalan dibawah mulut. Ciri lobster air tawar betina adalah adanya lubang bulat yang terletak didasar kaki ke-3. Berdasarkan capitnya, calon induk jantan memiliki ukuran capit 2-3 kali lebar buku pertama (tangkai capit) dan calon induk betina memiliki ukuran capit yang sama atau 
1,5 kali buku pertama (Lengka dkk, 2013)

Setelah 1 minggu induk betina diperiksa apakah sudah ada yang bertelur dengan ciri-ciri ekor dilipat rapat sampai ke kaki jalan ke-5. Agar lobster cepat bertelur maka hal-hal yang harus dilakukan adalah jumlah shelter tidak boleh berlebihan supaya lobster sering berinteraksi, dan pemberian pakan tambahan seperti cacing, keong atau taoge. Menurut Iskandar (2003), induk betina akan mulai bertelur setelah 10-15 hari sejak induk jantan mengawininya.

Penyusunan akuarium pada pembenihan lobster dapat dilihat pada Gambar 1 berikut :

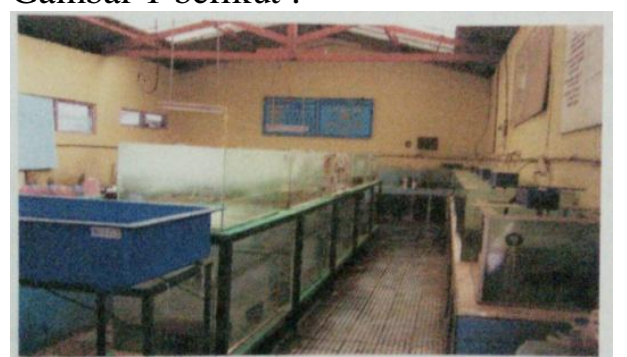

Gambar 1. Penyusunan Akuarium pada Pembenihan LAT di UPBAT Punten

\section{Pengeraman dan Penetasan Telur}

Pengeraman telur lobster air tawar dilakukan secara individu pada akuarium pengeraman dan penetasan. Lobster yang sudah bertelur dipisahkan dari tempat pemijahan dengan hati-hati dengan cara dipindahkan beserta shelternya agar tidak berontak yang dapat mengakibatkan kerontokan telur. Sebagian air (kira-kira sebanyak 10 liter) diambil dari media pemijahan dan dipindah ke pengeraman lalu ditambahkan air baru, dengan tujuan supaya lobster tidak stress. Media akuarium yang digunakan sebaiknya transparan agar mudah dicek kondisi induk dan telurnya.

Selama masa pengeraman pemberian pakan cukup sedikit saja kira-kira $1 \%$ dari berat badan karena aktifitas induk lebih banyak diam di dalam shelter. Waktu pengeraman antara 35-45 hari tergantung suhu air. Makin hangat suhu, maka telur akan semakin cepat menetas. Suhu optimal menurut Sukmajaya dan Suharjo (2003) adalah suhu 26-30 ${ }^{\circ} \mathrm{C}$. Telur yang menetas akan menjadi anakan atau burayak berukuran 4-5 $\mathrm{mm}$. Telur menetas seluruhnya sekitar 3-5 hari, setelah itu induk dapat dipindahkan dan dikarantina karena biasanya akan moulting.

\section{Pemeliharaan benih Persiapan Wadah Juvenil}

Benih atau anakan yang sudah dirontokkan dari induknya dipelihara di bak fiber yang di dalamnya diberi rumbai-rumbai dari tali rafia. Fungsi rumbai-rumbai ini adalah tempat bergelantungan atau persembunyian benih atau anakan lobster. Fiber juga dilengkapi dengan heater untuk menjaga suhu tetap optimal, karena suhu air di Punten sangat rendah. Penambahan aerasi dalam bak fiber diperlukan untuk menambah jumlah oksigen dalam air. Menurut Iskandar (2003), aerator berfungsi untuk mempertahankan oksigen terlarut dan menjaga kesegaran air.

\section{Perontokan Benih}

Dilakukan pada awal minggu ke-6 atau setelah benih yang lepas dari induk kira-kira 70\%. Menurut setiawan (2006), ketika anakan sudah lepas sekitar 70\%, sebaiknya sisanya yang masih menempel sebanyak 30\% dirontokkan saja karena dikhawatirkan naluri keibuannya sudah hilang akibat terlalu lama menggendong telur yang berakibat induk lobster akan memangsa anaknya.

Setelah semua benih rontok, maka induk dipindahkan kembali dalam akuarium pemijahan supaya dapat kawin lagi. Menurut Wiyanto (2003), induk betina yang sudah menetaskan telur akan dapat bertelur kembali dalam waktu 3 sampai 4 minggu. Produksi benih tiap siklus pemijahan berkisar 4000 ekor.

\section{Pembesaran Juvenil}

Setelah umur 1 bulan dilakukan penyortiran ukuran dengan tujuan agar 
benih tumbuh merata setiap ukuran, sehingga persaingan untuk mendapatkan makanan sama dan menghindari kanibalisme.

\section{E. Kematian Benih}

Kematian benih lobster akibat serangan hama atau penyakit sangat jarang terjadi. Dalam 1 (satu) kelompok anakan biasanya angka kematian kirakira $10 \%$ karena tidak mampu beradaptasi. Menurut Setiawan (2006), kematian benih juga dipicu oleh kegagalan dalam pergantian kulit.

Tingkat kelulushidupan benih di UPBAT sebesar $80 \%$, sehingga dari 12.000 ekor benih yang menetas dalam 1 tahun, yang masih bertahan hidup adalah 9.600 ekor. Jika diperhitungkan bulanan maka setiap bulan rata-rata dapat menjual 800 ekor benih. Benih lobster ukuran 0.5 inci harganya Rp.750,- sehingga hasil yang didapat perbulan adalah $800 \times$ Rp.750,- $=$ Rp.600.000,- Benih sudah dapat dipelihara di kolam pembesaran sampai ukuran konsumsi (100 gr) pada umur 78 bulan.

\section{F. Pemberian Pakan}

Pakan yang diberikan selama pemeliharan lobster air tawar adalah pelet udang komersial yang diberikan dengan dosis 3\% dari berat biomassa yang ditebar secara merata ke dalam bak dengan frekuensi 2 kali sehari untuk benih. Hal ini sesuai dengan pendapat Sukmajaya dan Suharjo (2003), menyatakan bahwa jenis pakan yang cocok untuk benih lobster air tawar adalah pelet udang komersial dengan dosis $3 \%$ karena memiliki protein yang tinggi.

Masa larva, terutama setelah melepaskan diri dari induknya, merupakan salah satu masa yang kritis dari seluruh siklus hidup lobster air tawar selain masa moulting (Anonymous, 2005; Jacinto, 2003). Menurut Djajasewaka (1985), untuk melewati masa kritis tersebut, hal penting yang harus diperhatikan adalah pemberian pakan tambahan. Pakan tambahan bisa berupa pelet dan pakan alami.

Pemberian pakan di UPBAT Punten disesuaikan dengan ukuran lobster. Ukuran burayak menggunakan pelet yang dihaluskan atau kuning telur yang sudah direbus. Cara pemberiannya yaitu sedikit kuning telur diletakkan di atas kain kemudian diperas untuk diambil sarinya, sedangkan ampasnya dibuang. Jika ampas ikut diberikan, maka dikhawatirkan akan menimbulkan jamur. Menurut Setiawan (2006), setelah menetas anakan lobster tidak cocok diberi pakan dari jenis sayuran atau mbiumbian. Buwono (2000) menyatakan sebaiknya benih lobster setelah berumur 1 minggu diberi cacing sutra segar dan daphnia beku yang mengandung sumber protein dan lemak hewani untuk memacu pertumbuhan.

\section{Pengelolaan dan Pengaturan Kualitas Air}

Untuk menjaga kebersihan wadah dan air, maka wadah pemeliharaan harus dibersihkan secara rutin. Pembersihan dapat dilakukan dengan 2 (dua) cara yaitu menyedot kotoran dengan slang (disifon) atau dengan cara menguras serta membersihkan wadah. Di UPBAT pembersihan akuarium dilakukan setiap hari dengan cara disifon untuk mengambil kotoran lobster dan sisa pakan. Sedangkan pengurasan akuarium dilakukan seminggu sekali. Pengendapan kotoran di dasar bak yang tidak dibersihkan dapat mengakibatkan lobster mengalami stress dan nafsu makan berkurang.

Pengaturan kualitas air yang dilakukan di UPBAT dilakukan $2 \mathrm{x}$ sehari pagi dan sore meliputi pengukuran suhu, derajat keasaman $(\mathrm{pH})$ dan kandungan oksigen terlarut (DO). Kisaran suhu di UPBAT antara 25-26 ${ }^{0}$ C. Menurut Setiawan (2006), suhu ideal untuk pemeliharaan lobster adalah $25-26{ }^{\circ} \mathrm{C}$. jika suhu di bawah atau di atas batas optimum akan membahayakan kehidupan lobster air tawar. Itulah sebabnya digunakan heater 
untuk mengatur suhu agar tetap terjaga sesuai kisaran yang diinginkan.

Hasil pengukuran $\mathrm{pH}$ di UPBAT didapatkan nilai $\mathrm{pH}$ berkisar antara 7-8. Hal ini sesuai dengan pendapat Wiyono dan Hartono (2003), sehingga pH di UPBAT dikatakan layak untuk pembenihan.

Oksigen sangat diperlukan untuk pernafasan dan metabolism. Kelarutan oksigen dalam dipengaruhi oleh kelancaran difusi dari udara ke dalam air (Lesmana, 2003 dalam Rizmawan, 2011). Dari hasil pengukuran menggunakan DO meter didapatkan kadar oksigen terlarut berkisar antara 5,2-6 ppm. Menurut Iskandar (2003), kandungan oksigen terlarut harus tetap berada di atas 3 ppm.

\section{G. Pemanenan dan Pemasaran}

Pemanenan lobster dapat dilakukan dengan 2 (dua) cara yaitu tanpa pengurasan atau dengan pengurasan air akuarium. Panen lobster dilakukan apabila ada permintaan dari pembeli. Sebelum benih dipanen, lebih dahulu tempat persembunyian diangkat lalu benih ditangkap dengan menggunakan saringan. Cara ini dilakukan tanpa menguras akuarium. Untuk benih berukuran 1 inci dapat dilakukan dengan menyedot benih menggunakan selang lalu ditampung di saringan. Alat yang digunakan untuk panen yaitu saringan kecil untuk mengambil lobster, saringan besar atau seser untuk menampung benih lobster yang disedot dengan selang, serta plastik untuk menyedot benih yang berukuran $1 \mathrm{~cm}$ dan bak plastik untuk menampung air.

Pemasaran benih lobster yang akan dijual ke konsumen di luar kota harus dikemas dengan baik agar kualitas benih dapat dijaga. Pengemasan dapat dilakukan dengan 2 (dua) cara yaitu pengemasan kering dan pengemasan basah dalam air. Proses pengemasan basah dilakukan dengan cara benih dimasukkan plastik seperti proses mengemas ikan hias, tapi jumlah plastik dua lapis agar tidak terjadi kebocoran akibat capit lobster. Caranya adalah kantung plastik diisi air sepertiga wadah, setelah itu benih dimasukkan dan diberi rumbai-rumbai dari tali rafia yang berfungsi sebagai tempat bergantungan lobster. Selanjutnya wadah berisi lobster diisi dengan oksigen dan diikat dengan tali rafia atau karet yang kuat. Lobster ditata berjajar dan sebaiknya tidak ditumpuk.

Pengemasan kering dapat dilakukan untuk benih berukuran 1 inci atau lebih. Wadah terbuat dari kotak plastik ukuran 20x15x10 $\mathrm{cm}$ dan dimasukkan ke dalam styrofoam. Wadah diberi daun papaya supaya lobster tidak mabuk dalam perjalanan dan styrofoam diberi lubang untuk tempat masuknya udara. Teknik pengemasan kering dapat dilihat pada Gambar 3 .

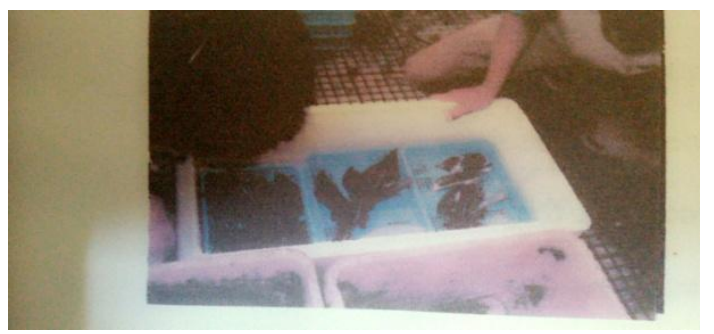

Gambar 3. Teknik Pengemasan Kering

\section{KESIMPULAN DAN SARAN}

Teknik pembenihan lobster air tawar di UPBAT Punten Batu dilakukan secara intensif dengan kegiatan meliputi : pengadaan dan seleksi induk, pemijahan, pengeraman, pemeliharaan benih, pemberian pakan, pengelolaan dan pengaturan kualitas air, serta pemanenan, pengemasan dan pemasaran.

Produksi benih yang dihasilkan pertahun adalah 12.000 ekor benih dengan survival rate (SR) sebesar $80 \%$. Induk yang dipijahkan adalah induk matang gonad berusia 5-6 bulan dengan panjang tubuh 4-5 inci. Hasil rata-rata pengukuran kualitas air di UPBAT adalah suhu berkisar $25-26{ }^{0} \mathrm{C}, \mathrm{pH}$ antara 7-8 dan DO berkisar 5,2-6 ppm.

Disarankan agar selalu menjaga suhu akuarium tetap optimum karena hawa di UPBAT Punten Batu cukup dingin, sehingga penggunaan heater 
mutlak diperlukan selama pembenihan berlangsung, serta menjaga kebersihan dan sirkulasi air untuk mencegah timbulnya penyakit yang tidak diinginkan.

\section{DAFTAR PUSTAKA}

Anonymous. 2005. Aquaculture of Non Endemic Species-Redclaw Crayfish. http://www.fish.wa.gov.au/docx /mp/mp100/index.php.Akses

Buwono. 2000. Kebutuhan Asam Amino Esensial dalam Ransum Ikan. Kanisius. Yogjakarta

Iskandar. 2003. Budidaya Lobster Air Tawar. Agromedia Pustaka. Jakarta

Jacinto, EC. 2003. Effect of Dietary Protein Level on Growth and Survival of Juvenile Freshwater Crayfish

Cherax quadricarinatus. Aquaculture Nutrition. Volume 9

Lengka, K. Magdalena K, Siti A. 2013. Teknik budidaya lobster (Cherax quadricarinatus) air tawar di balai budidaya air tawar (BBAT) Tatelu. J. Budidaya Perairan Jan 2013 Vol. 1 (1) : $15-21$

Lukito, A dan Prayugo, S. 2007, Panduan Lengkap Lobster Air
Tawar, penebar swadaya. Jakarta.

Rizwan,

M.

2011.

https://universitasasahan.

files.wordpress.com/2011/09/pe

mbenihan-cherax-

quadricarinatus.pdf

Setiawan, 2006. Teknik Pembenihan

Dan Cara Cepat Pembesaran

Lobster Air Tawar. PT. Agromedia Pustaka. Jakarta.

Sukmajaya, Y dan Suharjo, 2003. Mengenal lebih Dekat Lobster Air Tawar, Komoditas Perikanan Prospektif. Agromedia Pustaka Utama. Sukabumi.

Susanto, N. 2010. Prospek Pengembangan Berbagai Jenis Lobster Air Tawar Sebagai Biota Akuakultur di Indonesia. FMIPA Universitas Lampung.

Wiyanto, RH dan Hartono, R. 2003. Lobster Air Tawar Pembenihan dan Pembesaran. Penebar Swadaya. Jakarta

Wiyanto. RH dan Hartono, R. 2006. Merawat Lobster Hias di Aquarium. Penebar Swadaya. Jakarta 